\title{
Review on Social Protection for Vulnerable Group in Cambodia to Poverty Reduction
}

\author{
Rathny Suy (Corresponding author) \\ School of Public Affairs, University of Science and Technology of China, \\ Hefei, Anhui, 230026, China \\ Tel: +86-18755182753Ｅ-mail: rathny@mail.ustc.edu.cn
}

Leaksmy Chhay

School of Management, University of Science and Technology of China, Hefei, Anhui, 230026, China

Tel: +86-1515093101Ｅ-mail: leaksmy@mail.ustc.edu.cn

Dinara Bekbauova

School of Public Affairs, University of Science and Technology of China, Hefei, Anhui, 230026, China

Tel: +86-13075566310Ｅ-mail: 2501673971@qq.com

Aigul Islamjanova

School of Public Affairs, University of Science and Technology of China, Hefei, Anhui, 230026, China

Tel: +86-18655377002_E-mail:kedy_90@mail.ru

Issah Iddrisu

School of Public Affairs, University of Science and Technology of China, Hefei, Anhui, 230026, China

Tel: +86-18755185009Ｅ-mail: issah@mail.ustc.edu.cn 
Received: May 21, 2017 Accepted: June 26, 2017 Published: June 26, 2017

doi: 10.5296/jsss.v5i1.11458

URL: http://doi.org/10.5296/jsss.v5i1.11458

\begin{abstract}
Social protection is a principal device in progressing comprehensive development and, supportable and socially just development; moreover, social protection has ascended as a widespread arrangement of instruments planned to help individuals, households and communities to better manage risk, shocks and extreme poverty. The National Social Protection Strategy of Cambodia gives the particular purpose of social protection as that assists people cope with major sources of poverty and vulnerability while in the meantime advancing human development. It comprises of abroad set of arrangements and instruments intended to ensure people, households and communities against the financial, economic and social results of diverse dangers, risks, shocks and to bring them out of poverty. In Cambodia, social protection has expanded more thought since the arrival of the National Social Protection Strategy for the Poor and Vulnerable (NSPS) in 2011. The NSPS provides policy guidelines and activity arrangements to reinforce the social protection system in the country. Institutionally, the experience of a social safety net is nothing new to Cambodia, but the term and understanding might be conceptually separate. Cambodia is facing significant sources of vulnerability. The majority of vulnerable groups are children, women, people with disability, and the elderly. Poverty, growth inequality, social exclusion and lack of access to public services and opportunities are the main causes of vulnerability. This paper depicts about social protection policy of Cambodia, scope of SP, and presently facing the challenge of social protection in Cambodia; furthermore reviews on social protection framework and existing of social protection to reduce poverty that being embraced by government intervention.
\end{abstract}

Keywords: Social protection, Vulnerable group, Poverty reduction, Cambodia

\title{
1. Introduction
}

Social protection is a major arena of government activity aimed at ensuring that vulnerable population groups receive appropriate and effective public support to ensure their financial security and to safeguard their health (Bloom, Jimenez, \& Rosenberg, 2011). Social protection is a principal device in progressing comprehensive development and, supportable and socially just development; moreover, social protection has ascended as a widespread arrangement of instruments planned to help individuals, households and communities to better manage risk, shocks and extreme poverty (Kem, 2011; Vannarith, 2014).

Social protection is broadly understood encompassing a range of public programs which transfers in cash or in kind and provided insurance Sometimes the term "social security" is used interchangeably with "social protection" (Ravi, 2014). The Social Council and United Nations Economic states that social protection should be "broadly understood as a set of public and private policies and programs undertaken by societies in response to various 
contingencies in order to offset the substantial reduction or absence of income from work; provide assistance to people with health care and housing; and provide families with children" (United Nations, 2000). The Social Protection Strategy Paper from the World Bank moves beyond 'traditional' social protection in defining a 'social risk management' system including financial market and macroeconomic strength improvement to run of the social protection programs (Armando, David, \& Andrew, 2005). Social risk management (SRM) consists of public interventions "to assist households, communities, and individuals, in better managing income risks" (Robert, 2001). Social protection also can be defined by "entitlement to benefits that society provides to households and individuals - through public and collective measures - to protect against declining living standards or low arising out of a number of basic risks and needs" (Wouter, 2000). The National Social Protection Strategy of Cambodia provides the specific purpose of social protection as that helps people cope with major sources of poverty and vulnerability while at the same time promoting human development. It consists of abroad set of arrangements and instruments designed to protect individuals, households and communities against the financial, economic and social consequences of various risks, shocks and impoverishing situations and to bring them out of poverty (RGC, 2011). Social protection interventions include, at minimum, social safety nets, social welfare services, social insurance, and labor market policies (RGC, 2011; Vannarith, 2014). In Cambodia, social protection has increased more consideration since the release of the National Social Protection Strategy for the Poor and Vulnerable (NSPS) in 2011. The NSPS provides policy guidelines and activity arrangements to strengthen the social protection system in the country (Vannarith, 2014). In Cambodia, social protection has increased more consideration since the release of the National Social Protection Strategy for the Poor and Vulnerable (NSPS) in 2011. The NSPS provides policy guidelines and activity arrangements to reinforce the social protection system in the country (Vannarith, 2014). The government is actuated by the Constitution and several laws to give a scope of social safety nets to the people. Likewise, social protection related objectives are prioritized in the complete National Strategic Development Plan (NSDP). Under NSDP, various policies and action plans have been correspondingly perceived by related ministries and institutions. The diversity of social protection programs for the poor plans to address issues of vulnerability and human capital development (Kem, 2011).

The review paper is to give an outline of social protection circumstance in Cambodia. In particular, this paper recognizes vulnerable group and causes of vulnerability, and reviews the social protection framework and existing of social protection to reduce poverty that being embraced by government intervention and its partner. Besides, this paper depicts about social protection policy of Cambodia, scope of SP, and presently facing the challenge of social protection in Cambodia.

\section{Background and Context}

\subsection{Brief History of Cambodia}

Within the last 3 decades, Cambodia has changed political administration more as often as possible as many of its neighboring countries. Especially, societies the formal and traditional 
systems have been transformed close by the political administration. The government was in a position to settle the starvation circumstance winning in 1979 and made moderate however enduring increases in reconstructing schooling and basic healthcare. Formalized through advancement and land appropriation in 1989, enhanced output and was well received by most, although vulnerable group is the most vital types of social security (K. Viviane, 1995). The remarkable achievements in terms of infrastructure, development and human rehabilitation are very significant. After a transition from presenting a free market economy in the early 1990s, war to peace, and being integrated into international trade, Cambodia embarked on a new development path with an annual growth rate of around $6 \%$ in the last three decades (Vannarith, 2014; Vathana, 2010). International development assistance, trade openness, and a progressive inflow of external direct investment play critical roles in socio-economic development and poverty reduction (Vannarith, 2014). The poverty rate was lessened from $53 \%$ in 2004 to $20.5 \%$ in 2011(World Bank, 2014). This means that two out of ten Cambodians are deficient in 2011, contrasted and five out of ten in 2004. In 2012, the human development index (HDI) esteem for Cambodia was 0.543, ranked at 138 out of 187 countries and territories (Vannarith, 2014). It shared the same rank with Lao PDR; between 1995 and 2012, Cambodia's HDI esteem expanded from 0.411 to 0.543 , an expansion of $32 \%$ or an average annual increase of $1.7 \%$ (UNDP, 2013).

As far as executing the Millennium Development Goals (MDGs), Cambodia has achieved marginally more than $50 \%$ of the targeted Cambodia Millennium Development Goals (CMDGs) (according to the study conducted in 2011). It achieved $48 \%$ for CMDG1 (to eradicate extreme hunger and poverty), $56 \%$ for CMDG2 (to promote gender equality and empower women), 58\% for CMDG3 (to advance sex correspondence and enable ladies), 63\% for CMDG4 (to reduce child mortality), 59\% for CMDG5 (improve maternal health), 57\% for CMDG6 (to ensure environmental sustainability), 38\% for CMDG7 (to guarantee ecological supportability), and 59\% for CMDG8 (to develop a global partnership for development) (Sherif, 2009).

\subsection{Demography}

The population structure of Cambodia mirrors the effect of the Khmer Rouge regime between 1975 and 1979, amid which mortality levels were elevated, especially for men, and richness levels decreased. In post-conflict times, a baby boom occurred which was a substantial extent of people aged 20 years or less. In 1998 Census, the total population of Cambodia was 11.4 million (NIS, 1998). It is expected to grow by two times to 20.3 million by 2021 . The country had an average annual growth rate of 2.49 percent in spite of the fact that an upgrade of the projection conducted after the census suggests a more moderate growth. Still, population growth in Cambodia is the most elevated among ASEAN countries, with the exception of Laos (Vathana, 2010). 
Table 1. Cambodian population index and projections

\begin{tabular}{|c|c|c|c|c|c|c|c|c|}
\hline $\begin{array}{l}\text { Demographic } \\
\text { Indicators }\end{array}$ & 1970 & 1980 & 1990 & 2000 & $2008^{*}$ & 2010 & 2020 & 2030 \\
\hline $\begin{array}{l}\text { Midyear } \\
\text { population } \\
(* 1000)\end{array}$ & 7,396 & 6,888 & 9,345 & 12,396 & 13,395 & 14,753 & 17,601 & 20,183 \\
\hline Growth rate $(\%)$ & -0.7 & 2.5 & 3.6 & 1.8 & & 1.8 & 1.6 & 1.1 \\
\hline $\begin{array}{l}\text { Total fertility } \\
\text { rate } \\
\text { (births/woman) }\end{array}$ & 6.5 & 7.4 & 6 & 3.7 & & 3 & 2.7 & 2.4 \\
\hline $\begin{array}{l}\text { Crude birth } \\
\text { rate/1000 } \\
\text { population) }\end{array}$ & 43 & 58 & 47 & 27 & & 26 & 23 & 18 \\
\hline $\begin{array}{l}\text { Life expectancy } \\
\text { at birth (years) }\end{array}$ & 38 & 37 & 52 & 59 & & 63 & 66 & 69 \\
\hline $\begin{array}{l}\text { Infant mortality } \\
\text { rate } / 1,000 \text { births }\end{array}$ & 199 & 228 & 144 & 82 & & 53 & 38 & 27 \\
\hline $\begin{array}{l}\text { Under } \\
\text { mortality } \\
\text { rate/1,000 births }\end{array}$ & 274 & 327 & 185 & 104 & & 67 & 47 & 33 \\
\hline $\begin{array}{l}\text { Crude death } \\
\text { rate } / 1,000 \\
\text { population }\end{array}$ & 24 & 28 & 15 & 9 & & 8 & 7 & 7 \\
\hline
\end{tabular}

* Data from 2008 general census.

Source: National Institute of Statistics.

In 2008 , from the total population of $13,395,682$ people, only $4.39 \%$ were employed by the government, and another $0.25,0.07$ and $0.24 \%$ were employed separately in state-owned enterprises, non-profit institutions and embassies or global establishments which later in this paper would be examined inside the framework of the social security system (NIS, 2008). Agriculture sector (including forestry and fishery) employed $72.29 \%$ of the population where the extent of employed women in this part $(75.11 \%)$ is marginally higher than men $(69.38 \%)$ (Vathana, 2010).

\subsection{The Status of Vulnerable Group in Cambodia}

The forthcoming National Social Protection Strategy (NSPS), defines vulnerable people as (1) those living below the national poverty line, (2) those who cannot cope with shocks and or have a high level of exposure to shocks (people living under or near the poverty line tend to be the most vulnerable), and (3) infants and children, women and girls of reproductive age, 
food-insecure households, ethnic minorities, the elderly, the chronically ill, people living with HIV/AIDS and people with disabilities (Kem, 2011; RGC, 2011).

Pregnant women, children, and the elderly are the most vulnerable groups. The maternal mortality rate remains high although it has been reduced remarkably over the years. Worldwide, there are 430 maternal deaths per 100,000 live births (Vannarith, 2014). In Cambodia, there are 437 deaths per 100,000 live births, making maternity-related complications one of the leading causes of death for Cambodian women ages 15 to 49 (PRB, 2003).

Lack of skills, low production, unemployment, and underemployment is the principal sources of vulnerabilities for the young and adults groups. Labor-intensive industries, for example, garment and construction are the two vital sources of employment for this working age group. Poor working conditions, conventional wages, and the lay-offs are the center issues facing factory workers (Vannarith, 2014).

Child mortality levels in Cambodia stay high by local standards. Consistently, an anticipated 50 children under five years of age die mostly from preventable and treatable diseases such as diarrhea and pneumonia. While the quantity of children being influenced by chronic malnutrition decreased slightly, the quantity of children experiencing intense ailing health has expanded. Significant drivers of poor nourishment in youthful kids are insufficient corresponding sustaining rehearses, poor cleanliness and an extreme predominance of illnesses, including diarrhea (Vannarith, 2014).

For the elderly and disabled group, low income and uncertainty after retirement are the foremost concerns. Only public servants are included in the public pension scheme but the amount of pension is insufficient. There is some support programs provided to the disabled, but with limited coverage (Vannarith, 2014).

Table 2. Age group and sources of vulnerability

\begin{tabular}{|c|c|c|c|}
\hline $\begin{array}{l}\text { Age } \\
\text { group }\end{array}$ & Main vulnerabilities & Progress to date & $\begin{array}{l}\text { Gaps } \\
\text { challenges }\end{array}$ \\
\hline $\begin{array}{l}\text { Early } \\
\text { childhood } \\
(0-\quad 4 \\
\text { years old })\end{array}$ & $\begin{array}{l}\text { - } \quad \text { Stunting; } \\
\text { - } \quad \text { Diseases (diarrhea and } \\
\text { pneumonia, dengue fever). }\end{array}$ & $\begin{array}{l}\text { - Some material and child } \\
\text { nutrition programs are in } \\
\text { place; } \\
\text { - Breastfeeding } \\
\text { awareness and practices. }\end{array}$ & $\begin{array}{l}\text { - Service } \\
\text { delivery is limited } \\
\text { and of poor } \\
\text { quality; } \\
\text { - Coverage is } \\
\text { not universal }\end{array}$ \\
\hline $\begin{array}{l}\text { Primary } \\
\text { school } \\
\text { age }(5-14 \\
\text { years }\end{array}$ & $\begin{array}{l}\text { - High dropout rates; } \\
\text { - Poor quality of } \\
\text { education; } \\
\text { - Child labor. }\end{array}$ & $\begin{array}{l}\text { - Scholarships and school } \\
\text { feeding programs help } \\
\text { improve school attendance; } \\
\text { - Some programs in place } \\
\text { to improve quality of }\end{array}$ & $\begin{array}{l}\text { - } \quad \text { Small } \\
\text { coverage; } \\
\text { - Weak } \\
\text { education system; }\end{array}$ \\
\hline
\end{tabular}




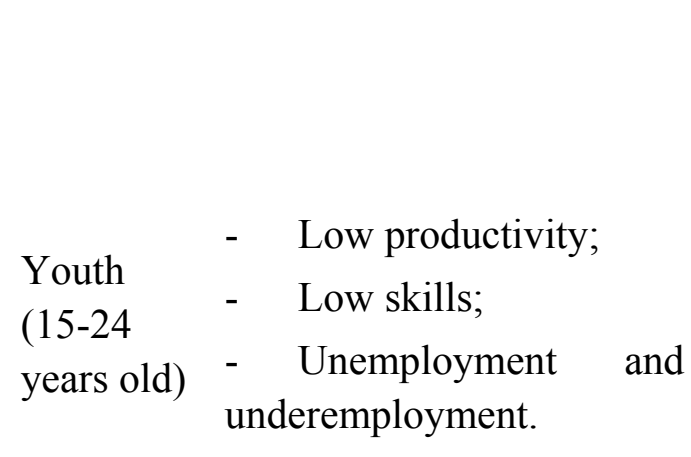

\begin{tabular}{lll} 
& \multicolumn{1}{c}{ Low } & labor \\
Adults & productivity; & \\
$(25-$ & $-\quad$ Low human capital \\
64 years & and skills; \\
old) & $-\quad$ Underemployment
\end{tabular}

Elderly - Low income; and - Underemployment; Disabled - Uncertainty. education.

- Education reforms;

- Further develop and invest in vocational training programs;

- University-industrial partnership apprenticeship.

- Public works program provide certain assistance;

- $\quad$ Skill programs.

development

- Teacher's quality and low salary rate.

- Structural

challenges

(corruption in the education system);

- Lack of and research and development.

\section{- Volatile}

funding and assistance; Lack of investment in skill development.

\section{- Pensions for civil servants;}

- Private coverage; insurance

- Some donor assistance to the disabled.

- No pensions for the poor;

- Very limited assistance provided to the disabled

$\begin{array}{llll}\text { All } \\ \text { groups }\end{array}-$ Health shocks. $\quad-$ Health equity funds are $-\begin{gathered}\text { Quality } \\ \text { health }\end{gathered}$

Source: Vathana, S. (2010); Vannarith, C. (2014).

In Table 2 shows about age group and sources of vulnerability, and it describes in detail on a vulnerable group of Cambodia. This information Based on the study by Sann, V. (2010), 'Social Protection in Cambodia: Toward Effective and Affordable Social Protection for the Poor and Vulnerable', in Asher, M. G., S. Oum and F. Parulian (eds.), Social Protection in East Asia - Current State and Challenges. ERIA Research Project Report 2009-9, Jakarta: ERIA. pp. 316-345. 


\section{Social Protection System in Cambodia}

\subsection{The Coverage of Social Security Schemes}

In 2002, law on Social Security Schemes for persons was promulgated by the provisions of the Labor Law. The Ministry of Labor and Vocational Training was established and is responsible for this legislation, whilst the Ministry of Social Affairs that following a government reorganization. Veterans and Youth Rehabilitation is responsible for the civil service social security system. Persons covered by the Social Security Schemes in this law regardless of nationality, race, sex, belief religion, political opinion, national extraction, social origin, membership of trade union or act in trade union are: (1) all workers defined by the provisions of the Labor Law, if those persons perform work in the territory of Cambodia for the benefit of an employer or employers, regardless of nature, form and validity of the contract done or kind and amount of the wage received by the person thereof; (2) state workers, public workers and all personnel who are not governed by the Common Statute for Civil Servants or by the Diplomatic Statute as well as officials who are temporarily appointed in the public service; (3) trainees, person who attend the rehabilitation center and apprentice shall deem to be workers; (4) Persons working in a self-employed profession; and (5) Seasonal or occasional workers (Vathana, 2010).

\subsection{Benefits for Sickness, Accident at Work, Maternity and Death}

\subsubsection{Sickness}

There are no qualifying conditions for entitlements such as a minimum length of service. Civil servants who fall sick are entitled to receive their full monthly salary, including location allowance, family and other allowances, whilst receiving medical treatment for a period of 3 months (if confined to hospital the patient is liable to pay for hospital food) but he/she continues to have the right to buy food and other goods from the State warehouse. For example, a civil servant that has 8 years services and if he/she is certified as incapable of working due to sickness he/she will receive a full monthly salary for 3 months and $90 \%$ of net monthly salary plus other allowances for the following 8 months (Vathana, 2010).

\subsubsection{Work-Related Accidents}

The condition of his her disease or injury will be placed in indicated in table 3. Persons who are evaluated at level 1 or 2 are eligible to apply for invalidity benefits. Those appraised at levels 3 and 4 who are still able to continue working will receive monthly cash support at $15 \%$ and $10 \%$ of monthly salary respectively of the injury or illness as an addition to his/her salary. If a civil servant has lost most of his/her physical ability and is not able to continue his/her work, the Ministry of Health or the Provincial/ City Health Directorate will assess the condition of his/ her injury or illness again in order to determine whether or not he/she will eligible to receive the Maximum Invalidity Pension. If he/she is old enough for retirement, he/ she will be eligible to apply for the maximum Retired Pension. Maximum invalidity pension is $65 \%$ of the final net monthly salary and applies to civil servants who lose their professional ability due to accidents at work or on mission (Vathana, 2010). 
Table 3. Level of disability and cash support benefit

\begin{tabular}{llll}
\hline Level of Disability & Disability (\%) & $\begin{array}{l}\text { Cash support } \\
\text { (months' salary) }\end{array}$ & $\begin{array}{l}\text { Sick leave on full } \\
\text { monthly salary (days) }\end{array}$ \\
\hline Level 1 & $81-100$ & 4 & 60 \\
Level 2 & $61-81$ & 3 & 45 \\
Level 3 & $41-60$ & 2 & 30 \\
Level 4 & $20-40$ & 1 & 15 \\
\hline
\end{tabular}

Scoure: MoSVY and MoLVT (Personal communication); Vathana, S. (2010)

\subsubsection{Maternity}

A pregnant civil servant is eligible for medical consultations and confinement care free of charge. For the first 12 months after giving birth, if the hospital has confirmed that she is sick or has no milk for breast-feeding the baby, she will be eligible to receive an additional cash support of 120 Riels per month for each child. For the first 12 months, during her working hours, a mother of a new born baby has the right to take 1 hour per day of her working time to feed the baby (Vathana, 2010).

\subsubsection{Death}

In the case of a death, the payments due are as follows: (1) On the death of civil servant by illness- 1,800 Riels for funeral costs and 6 months total salary plus monthly payments for a spouse of Riels 3,000 and for each eligible child Riels 3,100; (2) on the death of a pensioner, 1,800 Riels for funeral costs and 6 months total pension and monthly allowances for the spouse and children; and (3) on the death of civil servant from an accident or on mission, 2,000 Riels for funeral costs and 8 months total salary plus monthly payments for a spouse of Riels 3,000 and each eligible child Riels 4,000. Spouse payments are meant for life or until remarriage. Child payments are subject to an age limit of 15 years, unless the child is over age 15 and at school without a government scholarship up to a maximum age of 21 or disabled when he/she is not subject to an age limit (Vathana, 2010).

\subsection{Pensions}

The RGC pays a pension to an extensive number of its retired civil servants, military, police, disabled people and dependents of soldiers and military heroes. However, these amounts of payment do not meet daily living standards. Nevertheless, a civil servant having 30 years of civilian service may request early retirement, before the age of 55, while still benefiting from his/her retirement pension (Vathana, 2010). 
Table 4. Types of pension schemes and beneficiaries

\begin{tabular}{|c|c|c|}
\hline Type of Pensioner & $\begin{array}{l}\text { Estimated of total } \\
\text { beneficiaries }\end{array}$ & $\begin{array}{l}\text { Amount of Benefits } \\
\text { (millions, US\$) }\end{array}$ \\
\hline Retired civil servants* & 19,489 & 4.024 \\
\hline Retired military** & 5,151 & 1.140 \\
\hline Disabled military ( retired) $* * *$ & 31,121 & 7.010 \\
\hline Disabled civil servant ( retired)**** & 5,151 & 1.125 \\
\hline $\begin{array}{l}\text { Dependents of dead patriot } \\
\text { military***** }\end{array}$ & 54,895 & 2.400 \\
\hline $\begin{array}{l}\text { Dependents of dead civil } \\
\text { servants } * * * * * *\end{array}$ & 4,000 & 0.606 \\
\hline Total & 119,807 & 16.305 \\
\hline
\end{tabular}

Source: MoSVY and MoLVT (Personal communication); Vathana, S. (2010)

Notes:

* It also provide allowance to 13,364 spouse and 13,820 children, respectively

** It also provide allowance to 4,417 spouse and 12,132 children, respectively

$* * *$ It also provide allowance to 28,607 spouse and 91,328 children, respectively

**** It also provide allowance to 102,007 parents and 103,788 children, respectively

$* * * * *$ It also provide allowance to 4,000 children, respectively.

In Table 4 shows that the average payments by RGC through MoSVY to its civil servants, military, police, disabled people and dead and/or patriot-dead military, and for those who are their dependents, is estimated to be US\$16.4 million, benefiting 120,000 persons in 2005 . It is interesting to note that death civil servants and the dead military - either patriot or natural death - do not receive pensions but their dependents do, such as their children and their spouse and/or parents.

\subsection{Social and Health Insurance}

In the private sector, particularly workers from garment factories, insurance needs to be applied in order to be a member of the Garment Manufacturers Association in Cambodia (GMAC). In addition, GMAC has also worked closely with government ministries in order to foster and protect the interest of garment factories in Cambodia, and to work closely with the ILO in order to accredit labor standards. A study revealed that the total health insurance or cost for all garment factory employees is expected to be US\$1 million per annum.

There has been some success in piloting Community Social Health Insurance schemes which have been recently operated and assisted by donors and NGOs. A few NGOs have operated this scheme which targets the rural poor and urban communities. Currently in Cambodia a 


\section{Macrothink}

Journal of Social Science Studies

ISSN 2329-9150

2018, Vol. 5, No. 1

number of health reform proposals have been adopted, including official user fees, sub-contracting government health services delivery to non-governmental providers and Community Based Health Insurance (CBHI). As a result of these reforms, Social Health Insurance policies (SHI), led by the Ministry of Health $(\mathrm{MoH})$ are being devised. In addition, in terms of the development of a health insurance scheme for formal and non-formal sector employees, the sub-decree of the Social Security Law is yet to be approved by Council of Ministries (CoM) (Vathana, 2010).

\section{Challenge Facing Cambodia`s Social Protection}

\subsection{Poverty and Vulnerability Situation}

Cambodia has enjoyed significant economic growth over the past decade, averaging 7 per cent growth in gross domestic product (GDP) per year between 1997 and 2007. National data for 2004 and 2007 show that the national poverty rate dropped from $34.7 \%$ in 2004 to $30.1 \%$ in 2007 , detecting a rate of poverty reduction of $1.2 \%$ per year (RGC, 2011). Over the same period, per capita income doubled from US\$285 to US\$593 per year (GDP in 2008 amounted to \$711). Such growth has raised living standards and reduced poverty, which fell from an estimated 45 to 50 per cent of the population in 1994 to 35 per cent in 2004 and 30 per cent in 2007 (RGC, 2011). However, gaps between the rich and the poor and inequality between rural and urban areas are still challenging issue (see figure 1). And, in table 5 shows about poverty level of grouping people.

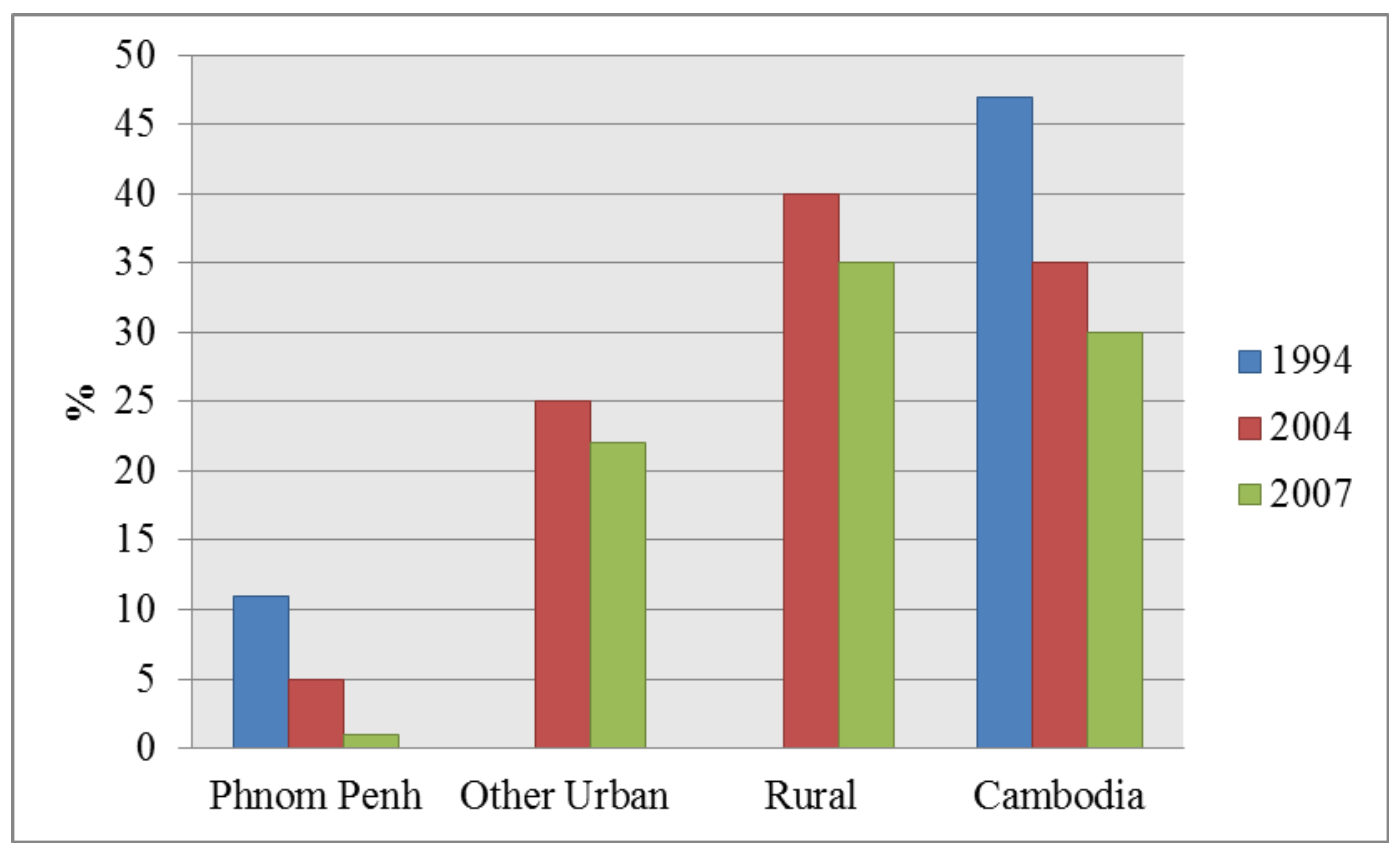

Figure 1. Poverty headcount, 1994-2007

Soure: CSES (2004), NSDP Update 2009-2013; RGC (2011) 
Table 5. Poverty levels of selected population groups

\begin{tabular}{llll}
\hline Group & \% Population & \% Poor & Poverty Gap \\
\hline Elderly (65 years old or above) & 4.3 & 25.9 & 5.5 \\
Employed & 53.3 & 28.3 & 6.6 \\
Members of female-headed households & 18.2 & 27.9 & 7.2 \\
Members of male-headed households & 81.8 & 31.0 & 7.5 \\
Members of employed-headed households & 91.1 & 31.0 & 7.5 \\
People with disabilities & 1.3 & 28.6 & 7.2 \\
Ethnic minorities & 2.2 & 36.1 & 10.0 \\
Infants (Below 1 year old) & 4.0 & 38.9 & 10.0 \\
Children (Ages 0-14) & 33.5 & 37.4 & 9.4 \\
Cambodia & 100 & 30.5 & 7.4 \\
\hline
\end{tabular}

Source: Cambodia Socio-Economic Survey (CSES) (2007).

Vulnerability is a reason for poverty, and in addition a sustaining and characterizing component of it. Poor households have a tendency to have less adapting methodologies to secure them against shocks, and vulnerable households are defenseless to be pushed into or more profound into poverty as a result of shocks (see Figure 2) (RGC, 2011).

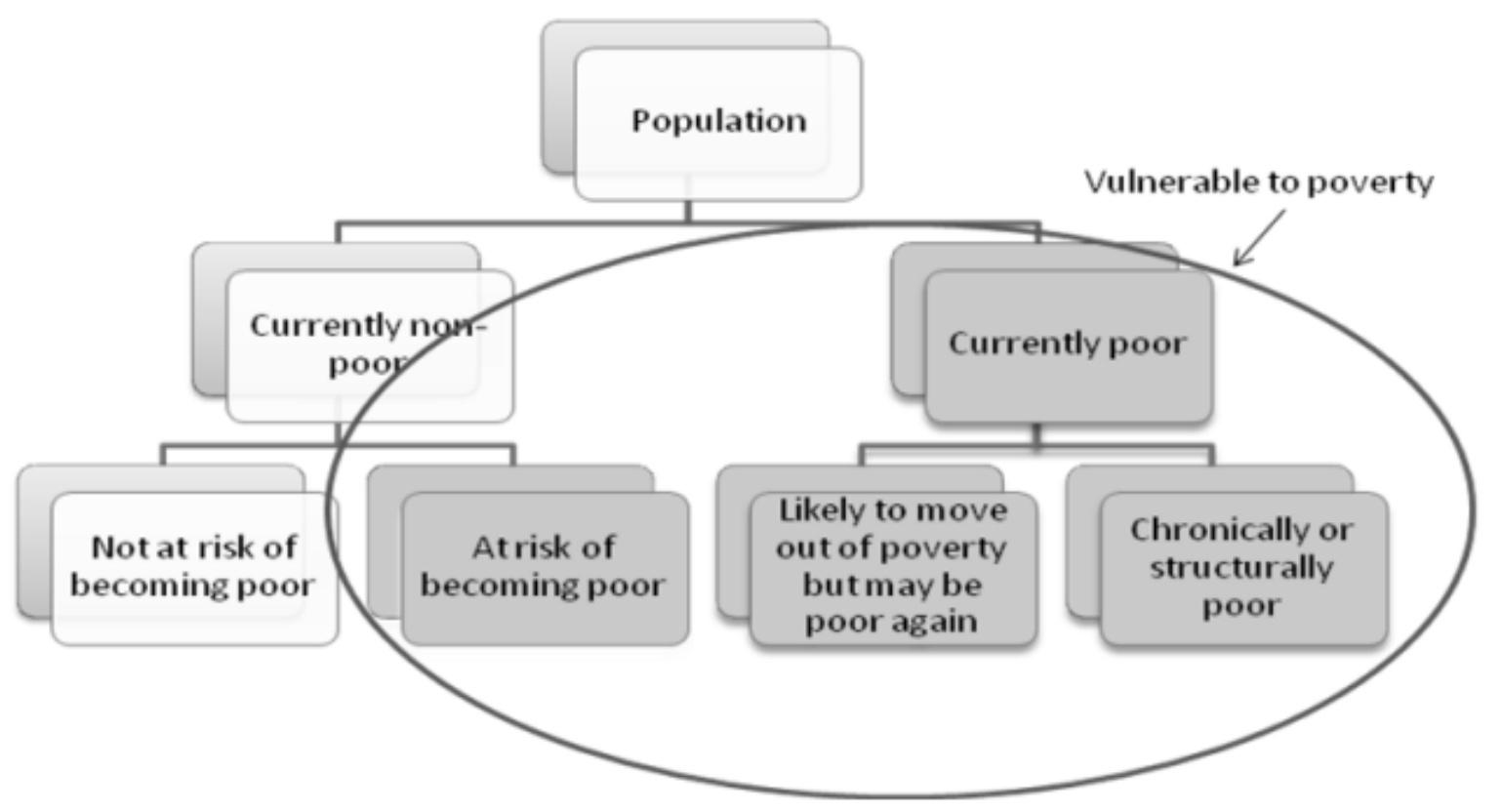

Figure 2. Poverty and vulnerability

Source: RGC (2011). 
Key risks and shocks can be divided into four categories: (1) emergencies and crises; (2) human development constraints; (3) seasonal unemployment and income insecurity; and (4) health shocks.

The global financial crisis is affecting Cambodia through dramatic declines in external demand within Cambodia's key manufacturing and service sectors. With food accounting for $60-70 \%$ of rural household expenditures and rice alone comprising $40-50 \%$, the high cost of food has had a significant impact on rural households, who represent roughly $90 \%$ of all poor in the country (Vathana, 2010). Overall, $82.7 \%$ of the households in Cambodia are net food consumers and $66.9 \%$ are net cereal clients (CRDB \& CDC, 2009). An increase in the prices of rice would have negative impacts on two thirds of households. Poor and net food buying households are the most affected and they generally reside in rural areas (CDRI, 2008). Emerging evidence suggests that recent global economic shocks are starting to reverse the progress carried out in previous years. Estimates up to and including 2007 suggest that child nutrition and survival rates, while poor, were improving over time (Sheila, Ellen, Rebecca, Mark, \& André, 2016). However, Cambodia Anthropometric Survey (CAS) in late 2008 suggests that the decline in child malnutrition and ill health has now stagnated and possibly started to reverse (CAS, 2008).

\subsection{Background of Social Protection in Cambodia}

Several organic laws have been passed to codify some of the social protection related tenets of the Constitution. The most relevant laws which have been adopted or are currently under consideration include: (1) the Labor Law passed in October 1998, embodies most of the ILO conventions on core labor standards, all of which Cambodia has ratified; (2) the Insurance Law passed in June 2000, provides a legal framework for better regulation of insurance market activities. However, these insurance schemes will benefit only a small proportion of the population in the initial stages and most likely will not be accessible to the poor; (3) the Law on Social Security Schemes for Persons Defined by the Provisions of the Labor Law passed in September 2002; (4) the law has been promulgated but not implemented since it requires a sub-decree on the National Social Security Fund (NSSF), which will cover employment injury insurance (EII), the pension scheme, and a short-term benefit system; (5) a National Action Plan to Combat Violence Against Women has been developed, and is being implemented in accordance with the Law on the Prevention of Domestic Violence and Protection of Victims adopted in 2005; and (6) the Law on Suppression of Trafficking in Humans and Sexual Exploitation, adopted in late 2007, consistent with the UN Palermo Protocol (RGC, 2011; Vathana, 2010).

Safety net interventions are scattered across several ministries. The Ministry of Social Affairs, Veterans and Youth Rehabilitation (MOSVY), the Ministry of Labour and Vocational Training (MOLVT) and the Ministry of Women's Affairs (MOWA) are all mandated with managing state social services for the wider population, and helping to protect specific vulnerable groups against risks (Vathana, 2010). In collaboration with the WFP, the Ministry of Rural Development (MRD) and the Ministry of Water Resources and Meteorology (MOWRAM) are also implementing food for work program (CRDB \& CDC, 2009). 


\section{Social Protection Existing to Vulnerability Reduction}

In Cambodia, Social protection has evolved both conceptually and practice and is now a key policy issue in vulnerability and poverty reduction. Hahn and Salim (2003) define social protection in the context of Cambodia as "formal and informal safety nets available to Cambodians to cope with shocks and threatening to push them into extreme poverty". Using this definition, two forms of existing social protection can be identified in Cambodian society: (1) informal social protection, and (2) formal social protection (Kem, 2011). Both of these assume essential parts in vulnerability reduction and fill in as a support for people during shocks and emergency or when they require offer assistance (Sudmeier-Rieux, 2014)..

\subsection{Informal Social Protection}

Informal social safety nets in Cambodian society come in the form of kinship, reciprocal activities, community cohesion and religious institutions, and have been playing a very important role in providing the poor and vulnerable in Cambodia with help and support for generations (Kem, 2011; Kim, 2011; McAndrew, 1998). Generally, informal social protection is part of community social capital and contributes to socioeconomic and community development and food security(Krishnamurthy, 1999); Consequences of war and social turbulence such as the breakdown of the nuclear and extended family unit, social dislocation and survival driven relocation left original traditional social protection systems in a fragile state and disrupted many communities' access to the kind of support that they have long relied upon (RGC, 1997). More recent studies even suggest that some forms of informal social safety nets, such as mutual help and reciprocal activities among vulnerable worker groups and some rural households, are close to collapsing due to extreme family hardship exacerbated by the global economic crisis and inflation (Kem, 2011).

\subsection{Formal Social Protection}

Formal social protection can encompass a wide range of measures, including the legal framework and policy interventions, social assurance, social safety nets and social assistance programs (Verena, 2011). By the end of 2009, 76 on-going social protection programs were being funded by the government and its development partners: 40 programs focus on health, 16 on education, 15 on community and social welfare and five projects focus on emergency relief and food aid (CARD/WFP/WB, 2009a).

\subsubsection{Legal Framework and Government Intervention}

The government is mandated by the Constitution to provide a number of social protection measures to the people. For instance, Article 22, "Everyone ...has right to social security"; Article 25, "The right to security in the event of unemployment, sickness, disability, widowhood, old age or other lack of livelihood in circumstances beyond [their]control"; Article 36, "Khmer citizens of either sex shall enjoy the right to choose any employment according to their ability and to the needs of the society..."; Article 46, "Prohibition of all types of exploitation and obscenities which affect the reputation of women...provision of adequate social support for women..."; Article 72, "The health of people shall be guaranteed...Poor citizens shall receive free medical consultation in public hospitals, 
infirmaries and maternities. The state shall establish infirmaries and maternities in rural areas"; Article 75, "The state shall establish a social security system for workers and employees" (Kem, 2011; RGC, 2011; Vannarith, 2014).

Several organic laws have been passed to codify some of the social protection related tenets of the Constitution. The most relevant laws which have been adopted are: (1) the Labor Law which provides a standard legal workweek, and the minimum permissible working age. (2) Insurance Law passed in 2000 to provide legal framework for better regulation of insurance market activities, including life insurance, pension, credit and natural disaster insurance; (3) the Law on Social Security Schemes that entitles workers and employees in the private sector to old age, invalid and survivors' benefits as well as workers' compensation; (4) the Law on Suppression of Human Trafficking and Sexual Exploitation heavily penalizes offenders if victims are below 15 years of age and gives the police more power to investigate and arrest suspected traffickers; (5) the Law on the Prevention of Domestic Violence and Victim Protection; and two more laws, yet to be commuted by the government, support retired civil servants and veterans (6) Law on the Comprehensive National Social Security Fund and (7) Law on National Pension for Veterans (Kem, 2011; RGC, 2011).

Before developing a national policy and strategy on social protection, Cambodia implemented social safety nets mainly funded by external sources to assist the poor and vulnerable to integrate and rehabilitate. The support programs include (1) food distribution to the areas and households facing food insecurity, (2) a feeding program at rural schools and a work-for-food scheme, (3) scholarships to support poor children to go to school, (4) public construction and infrastructure development in the areas hit by food insecurity and severe poverty, (5) a health equity fund and community-based insurance scheme to support the healthcare system for the poor, (6) a special healthcare program for the most vulnerable groups such as people with disabilities, the elderly, and orphans, and (7) other humanitarian assistances (Vannarith, 2014). The vision of National Social Protection Strategy (NSPS) is that more Cambodians, especially the poor and vulnerable, will benefit from improved social safety nets and social security as an integral part of sustainable, affordable and effective national social protection systems (CARD/WFP/WB, 2009b).

The Cambodian government has developed social protection policy with the overall aims to (1) develop and enhance human capital (health, education, livelihood), (2) reduce the vulnerabilities of poor people, (3) alleviate the impacts of climate change and natural disasters, (4) support the victims of natural disasters, (5) rehabilitate and integrate people with disabilities, orphans, poor widows/widowers, female-headed households, homeless people, veterans and their families, and the victims of drug addition, human trafficking, human rights abuse and violations, and (6) work in partnership with development partners and civil society groups to prevent crimes and provide justice to the local communities (Note 1) (Vannarith, 2014). The NSPS is necessary to promote the livelihoods of the people and to ensure achievement of the CMDGs. Rural economic development is to be achieved by rehabilitating and developing rural infrastructure, addressing seasonal unemployment and providing vocational training and microcredit support, as well as through interventions to ensure quality of life and social development (Note 2). 


\subsubsection{Expenditure on Social Protection}

The general trend of government spending on ministries working on social protection has expanded from $3.17 \%$ of GDP in 2006 to $3.9 \%$ in 2010, comparable to USD442.25 million. Nonetheless, it is still lower than the local level where average public spending alone was $4.3 \%$ of GDP in 2004 as according to the World Development Indicator (Kem, 2011). Given the administration's need to create human capital, the Ministry of Education and Ministry of Health get the biggest spending distribution; other social ministries, for example, the Ministry of Economics and Finance get under $0.5 \%$ of the budget allocation from GDP (Ardichvili, Zavyalova, \& Minina, 2012).

Table 6 . Government expenditure on social intervention in 2010 by region (million riel)

\begin{tabular}{lllllll}
\hline & \multicolumn{7}{c}{$\begin{array}{l}\text { Allowance } \\
\text { Secial Assistance } \\
\text { Social } \\
\text { Transfer }\end{array}$} \\
\cline { 2 - 7 } Phnom Penh City & $8,242.0$ & 71 & 844.0 & 29 & $9,086.7$ & 63 \\
\cline { 2 - 7 } Plain Region & 951.0 & 8 & 665.2 & 23 & $1,616.2$ & 11 \\
Tonle Sap Region & $1,083.0$ & 9 & 698.7 & 24 & $1,781.7$ & 12 \\
Coastal Region & 620.0 & 5 & 255.6 & 9 & 875.6 & 6 \\
Plateau & and & $\%$ & Amount & $\%$ & Amount & $\%$ \\
Mountainous & 735.0 & 6 & 434.3 & 15 & $1,169.3$ & 8 \\
Total & $\mathbf{1 1 , 6 3 1 . 0}$ & $\mathbf{1 0 0}$ & $\mathbf{2 , 8 9 7 . 8}$ & $\mathbf{1 0 0}$ & $\mathbf{1 4 , 5 2 9 . 5}$ & $\mathbf{1 0 0}$ \\
\hline
\end{tabular}

Sourse: Kem, S. (2011).

Most of the government's budget for social intervention is known as "allowance and social transfer" and "social assistantce" (Note 3). In Table 6 shows about the estimated total government expenditure for 2010 is 326,370 million riels or USD77.7 million, of which $4.45 \%$ is to be spent on social intervention and from which $3.56 \%$ goes to social assistance and $0.89 \%$ to allowance and social transfer. It is interesting to note that Phnom Penh region alone receives $71 \%$ of total expenditure on social assistance (Kem, 2011).

\section{Scope of Social Protection in Cambodia}

The national government promotes investment in social protection as a contribution to long-term poverty-reduction goals and a short-term emergency-/ shock-response measure to address the consequences of crises. The poverty and vulnerability of many Cambodians have been exacerbated since 2007 by food-price inflation and the global financial and economic crisis. Social protection is an interest in human development, inclusive growth and poverty reduction that adds to the accomplishment of the poverty target, which the economic crisis 


\section{Macrothink Institute ${ }^{\text {tM }}$}

has additionally extended. The National Social Protection Strategy for the Poor and Vulnerable (NSPS) is consequently anticipated to play a critical role in reducing poverty and inequality.

The RGC is propelling social protection for the formal sector while prioritizing expanding interventions pointed uncommonly at reducing poverty, vulnerability and risks for the poor and vulnerable. As to the medium term, the NSPS concentrates on social protection for the poor and vulnerable. The poor and vulnerable are defined as: (1) people living below the national poverty line; and (2) people who cannot cope with shocks and/or have a high level of exposure to shocks (of these, people living under or near the poverty line tend to be most vulnerable) (RGC, 2011). The NSPS prioritizes the development of effective and sustainable social safety nets targeted to the poor and vulnerable, with complementary social welfare services for special vulnerable groups, such as people living with HIV and orphans made vulnerable or affected by HIV (Note 4). The contributory intervention of community-based health insurance (CBHI) is also included, as it is targeted at the near poor who are vulnerable to falling into poverty as a result of health shocks. Figure 3 illustrates the scope of the NSPS (RGC, 2011).

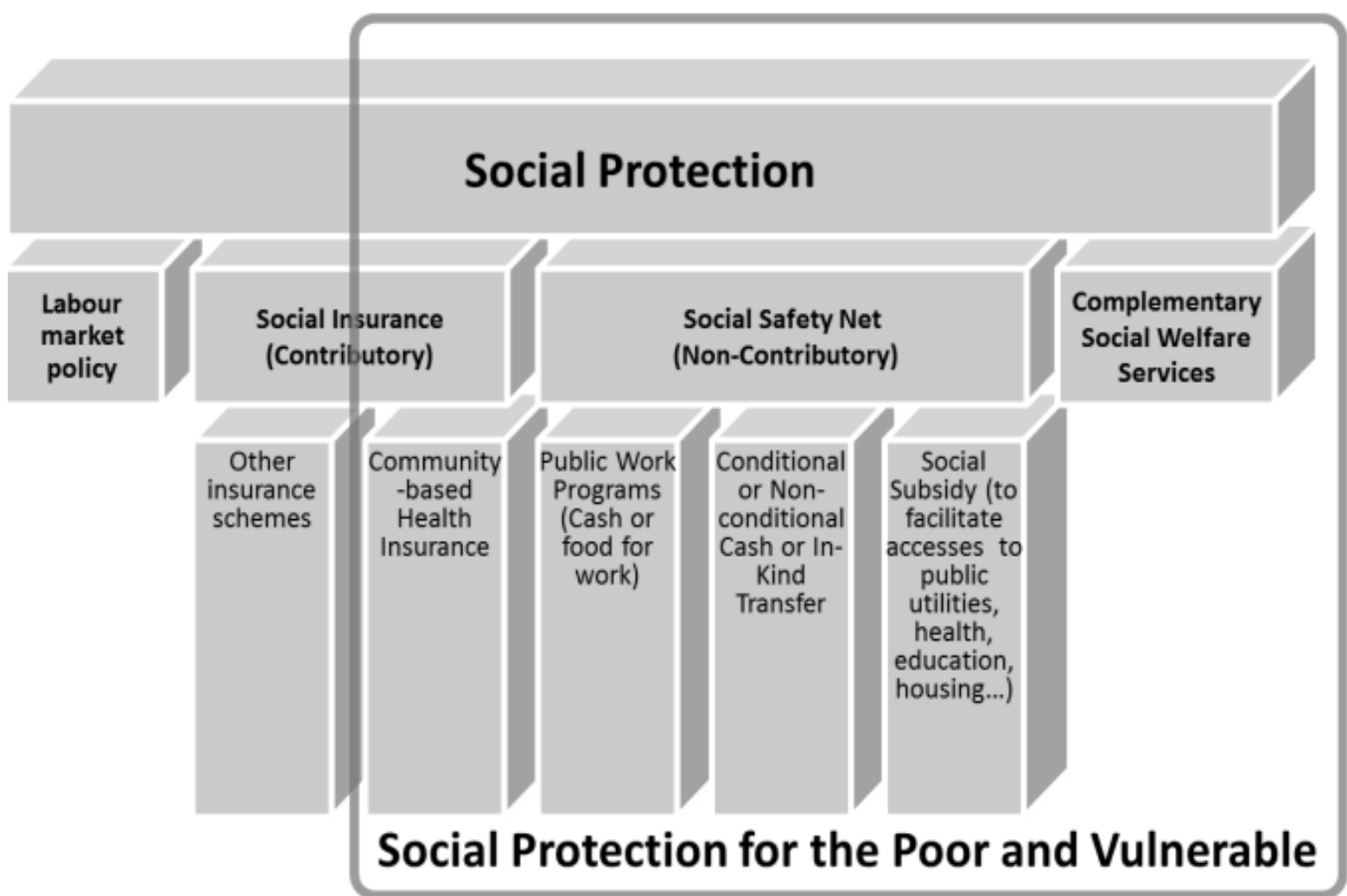

Figure 3. Scope of the NSPS, focusing on the poor and vulnerable

Source: RGR (2011).

In Figure 4 illustrates the relationship between coverage of basic noncontributory social protection for all and that of contributory social insurance for those with higher incomes, in 


\section{Macrothink}

particular formal sector workers. This includes both contributory and noncontributory schemes.

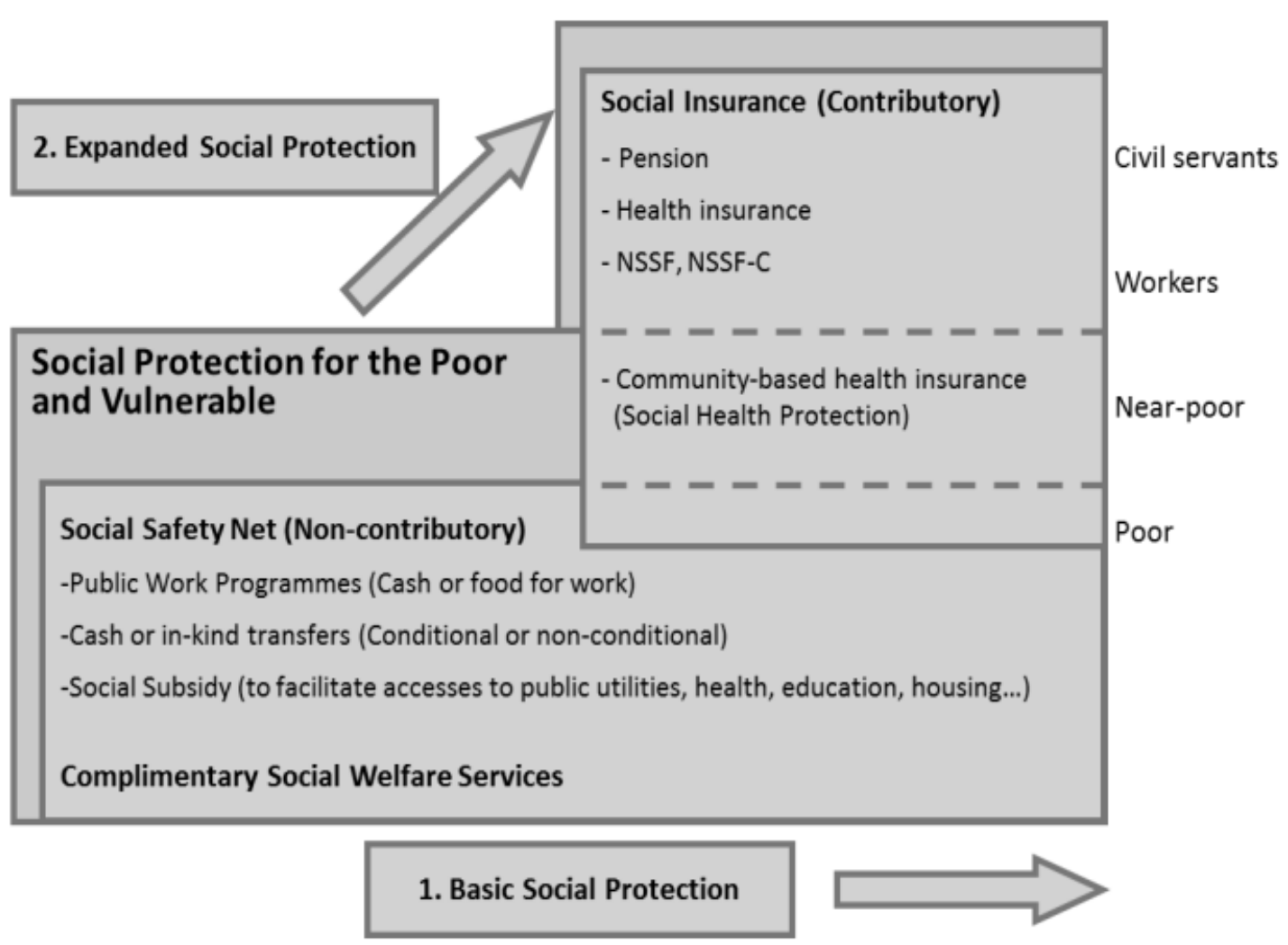

Figure 4. Gradual progression towards comprehensive social protection, as per the NSPS long-term vision

Source: RGC (2011).

The development of comprehensive social protection implies ensuring that the relevant components (non-contributory and contributory) are developed in parallel towards a sustainable system, whereby those who can afford social protection will access it based on their formal contributions and those who cannot rely on the state for support until they develop such capacity over time. There are linkages and complementarities between the two major components of a comprehensive system of social protection (Note 5).

\section{Challenges and Gaps of Social Protection}

Social protection programs in Cambodia may go up against a couple challenges identifying with execution, institutional and financing issues (ILO, 2001). From an implementation perspective, the challenge is the move from divided project-based interventions to the more coordinated and systematic program past 2013. While the present safety net interventions exclude some important vulnerable groups, the recently created National Social Protection Strategy for the Poor and Vulnerable (NSPS) is to incorporate the more extensive targets and scope of instruments of social protection and is focused as a response to vulnerability (Rachel \& Naila, 2003). 
Given the many sources of vulnerability confronted by the country's poor, safety nets should be a key part of the development of social protection (Tevera \& Simelane, 2014). Cambodia has actualized many major donor supported undertakings and programs to reintegrate, restore and enhance nourishment security; to adequately respond to emergency situations; and to enhance the livelihood of poor Cambodians. Still, the country has not yet made critical utilization of some types of safety net programs that have demonstrated effective in other countries - for example, the conditional cash transfers (programs that provide households with cash payments so long as they make use of public services). Institutionally, the experience of a social safety net is not new to Cambodia, but the term and understanding might be conceptually different.

In the course of the most recent year and a half, participatory dialogue among line ministries and government institutions with development partners has been amazingly noteworthy and this strategy must be supported in the long term. To wrap things up, inferable from the budget constraint, financing of the social protection program must be viewed as a venture instead of as expenditure.

\section{Concluding remarks}

Social protection is the center component in advancing inclusive growth and sustainable development. Cambodia has regulated social protection policy structures and action plans since 2009 after it was genuinely affected by the global financial and economic crisis. Cambodia is facing significant sources of vulnerability. Women, children, the elderly, and people with disability are the most vulnerable groups. Poverty, growth inequality, social exclusion and lack of access to public services and opportunities are the major causes of vulnerability. Vulnerable people experience different shocks at different levels. It was consistently found that all groups are very sensitive and less able to manage whenever struck by shocks. In 2011, the government issued policy guidelines to implement social protection for the vulnerable and the poor. However, the implementation of social protection is not applicable and the coverage is very limited. It is characterized by fragmented administration with various ministries, departments and organizations providing the protection. However, social protection policy is limited to social safety nets. It is required to expand its policy coverage and action plan to incorporate wider social, economic, and political reforms to address the structural issues of vulnerabilities, social justice, and people's participation. Applying the existing social protection programs remains exceptionally restricted because of resource constraints, institutional weakness, knowledge gaps, and poor coordination. Capacity building and skills development are therefore expected to adequately deliver social protection programs.

\section{Acknowledgement}

I would like to acknowledge to my supervisor, Professor Song Wei for his the support and motivation, especially thanks goes to the Chinese Scholarship Council (CSC) for the scholarship awarded me to pursue my $\mathrm{PhD}$ at the University of Science and Technology of China. I also would like to thank the anonymous reviewers and the academic editor of this journal for the invaluable comments and suggestions which have substantially improved the 
manuscript.

\section{References}

Ardichvili, A., Zavyalova, E., \& Minina, V. (2012). Human capital development: comparative analysis of BRICs. European Journal of Training and Development, 36(2/3), 213-233. https://doi.org/10.1108/03090591211204724

Armando, B., David, H., \& Andrew, S. (2005). Can Social Protection Tackle Chronic Poverty? European Journal of Development Research, 17(1), 1-29. https://doi.org/10.1080/09578810500066423

Bloom, D., Jimenez, E., \& Rosenberg, L. (2011). Social Protection of Older People: Program on the Global Demography of Aging.

CARD/WFP/WB. (2009a). Safety nets in Cambodia, Concept and Inventory. Phnom Penh, Cambodia: World Food Programme and World Bank.

CARD/WFP/WB. (2009b). Cambodia Safety Net Review, Policy Note. Phnom Penh, Cambodia: World Food Programme and World Bank.

CAS. (2008). Cambodia Anthropometrics Survey 2008: Initial findings. UNICEF-NIS, Phnom Penh, Cambodia: Cambodian Anthropometric Survey.

CDRI. (2008). Impact of High Food Prices in Cambodia. Phnom Penh, Cambodia: Cambodia Development Research Institute.

CRDB \& CDC. (2009). Council For Agricultural And Rural Development Technical Working Group on Food Security and Nutrition Background Paper On Social Safety Net In Cambodia; Phnom Penh, Cambodia: Cambodian Rehabilitation and Development Borad, Council for the Development of Cambodia.

ILO. (2001). Social security: Issues, challenges and prospects. Geneva 22, Switzerland: International Labour Organization.

K. Viviane, F. (1995). The Failure of Agricultural Collectivization in the People's Republic of Kampuchea 1979-1989: Monash Asia Institute.

Kem, S. (2011). Policy Options for Vulnerable Groups: Income Growth and Social Protection. Phnom Penh, Cambodia: CDRI.

Kim, S. (2011). Reciprocity: Informal Patterns of Social Interaction in a Cambodian Village (J. A. Marston Ed. Vol. 70): Monash University Press.

Krishnamurthy, V. (1999). The Impact of Armed Conflict on Social Capital: A Study of Two Villages in Cambodia. Phnom Penh, Cambodia: Social Services of Cambodia.

McAndrew, J. P. (1998). Interdependence in household livelihood strategies in two Cambodian villages. Phnom Penh, Cambodia: United Nations Research Institute For Social Development (UNRISD).

NIS. (1998). Cambodian General Demographic Survey 1998. [Demographic Census]. Phnom Penh, Cambodia: National Institute of Statistic, Ministry of Planning.

NIS. (2008). Cambodian General Demographic Survey 2008. [Demographic Census]. Phnom Penh, Cambodia: National Institute of Statistics, Ministry of Planning. 
PRB. (2003). Maternal Mortality a Leading Cause of Death in Cambodia. from http://www.prb.org/Publications/Articles/2003/MaternalMortalityaLeadingCauseofDeathinCa mbodia.aspx

Rachel, S.-W., \& Naila, K. (2003). Gender Equality and the Extension of Social Protection (Vol. 16, pp. 1-61). Geneva 22, Switzerland: International Labour Organization.

Ravi, K. (2014). Social Protection, Vulnerability and Poverty (pp. 1-13). Ithaca, New York 14853-7801 USA: Charles H. Dyson School of Applied Economics and Management, Cornell University.

RGC. (1997). First Five Year Socio-economic Development Plan 1996-2000. Phnom Penh, Cambodia: Royal Government of Cambodia.

RGC. (2011). National Social Protection Strategy for the Poor and Vulnerable. Phnom Penh, Cambodia: Royal Government of Cambodia.

Robert, H. (2001). Risk and Vulnerability: The Forward Looking Role of Social Protection in a Globalizing World (pp. 1-28). Washington, D.C. 20433 USA: Social Protection Unit Human Development Network The World Bank.

Sheila, I., Ellen, O. N. B., Rebecca, F. G., Mark, M., \& André, B. (2016). Improving Estimates of Numbers of Children With Severe Acute Malnutrition Using Cohort and Survey Data. American Journal of Epidemiology, 1-12.

Sherif, R. (2009). Achieving Cambodia's Millennium Development Goals: GAP Analysis: PriAct.

Sudmeier-Rieux, K. I. (2014). Resilience - an emerging paradigm of danger or of hope? Disaster Prevention and Management: An International Journal, 23(1), 67-80. https://doi.org/10.1108/DPM-12-2012-0143

Tevera, D., \& Simelane, N. (2014). Food for the Urban Poor: Safety Nets and Food-Based Social Protection in Manzini, Swaziland. Urban Forum, 25(2), 241-252.

UNDP. (2013). Cambodia: HDI values and rank changes in the 2013 Human Development Report (pp. 1-5). Phnom Penh, Cambodia: The Rise of the South: Human Progress in a Diverse World.

United Nations. (2000). Enhancing social protection and reducing vulnerability in a globalizing world, Report of the Secretary General to the Thirty-ninth Session E/CN.5/2001/2. Washington DC: United Nations Economic and Social Council.

Vannarith, C. (2014). Social Protection in Cambodia. Paper presented at the Social Protection Japan.

Vathana, S. (2010). Social Protection in Cambodia: Toward Effective and Affordable Social Protection for the Poor and Vulnerable. Jakarta: ERIA Research.

Verena, T.-R. (2011). Assessing The Formal Social Protection System in Mauritius. Research Journal of Social Science and Management, 1(6), 82-94.

World Bank. (2014). Poverty has fallen, yet many Cambodians are still at risk of slipping back into poverty, new report finds. from http://www.worldbank.org/en/news/press-release/2014/02/20/poverty-has-fallen-yet-many-ca mbodians-are-still-at-risk-of-slipping-back-into-poverty 


\section{Macrothink}

Wouter, v., Ginneken. (2000). The extension of social protection: ILO's aim for the years to come'. London: Social Protection: New Directions of Donor Agencies, Department for International Development.

\section{Notes}

Note 1. Remarks by Prime Minister Hun Sen, available at http://www.socialprotection.gov.kh/documents/publication/nsps\%20book\%20kh.pdf

Note 2. Remarks by Deputy Prime Minister Yim Chhay Ly, Chairman of Council for Agricultural and Rural Development, available at http://www.socialprotection.gov.kh/documents/publication/nsps\%20book\%20kh.pdf

Note 3. Social security fund includes: (1) family, (2) health and giving birth, (3) death, (4) retirement, (5) decommission from the armed forces, (6) work accident and Invalidity, (7) orphan of personal, (8) other, (9) return attenuation. Social assistance includes: (1) assistance for hospitalization, (2) natural disaster, (3) other social expenses, (4) support to social and cultural sector (including support to sport and cultural communities, orphanages, and the Red Cross), (5) donation to NGOs.

Note 4. The Law on the Prevention and Control of HIV/AIDS (Article 26) also enshrines the right of people living with HIV to primary health care services, free of charge, in the public health sector network.

Note 5. Including complementary coverage of benefits and services for population groups of different ability; and complementary financing mechanisms towards fiscal sustainability, whereby the contributory system to a large extent funds the development of the non-contributory system through its cross-subsidizing function and direct contribution to public revenues, as well as through stronger societal support to the system, including through taxation. The ultimate aim of the dual gradual system is ensuring universal coverage to protect the population against risks, shocks and chronic situations and vulnerabilities.

\section{Copyright Disclaimer}

Copyright for this article is retained by the author(s), with first publication rights granted to the journal.

This is an open-access article distributed under the terms and conditions of the Creative Commons Attribution license (http://creativecommons.org/licenses/by/3.0/). 